\title{
HUMAN RIGHTS MANIFESTATION THROUGH ENFORCEMENT OF COMMUNAL LAND OWNERSHIP RIGHTS FOR WOMEN IN MINANGKABAU
}

\author{
TAFKIR
}

Pasca Sarjana (S2) Aqidab Filsafat, Institut Agama Islam Negeri (IAIN) Bukittinggi,gampalatafkin@gmail.com

(C2021 by the authors. Submitted for possible open access publication under the terms and conditions
of the Creative Commons Attribution-ShareAlike 4.0 International License (CC-BY-SA)
license (https://creativecommons.org/licenses/by-sa/4.0/)
$D O I:$ http://dx.doi.ong/10.30983/bumanisme.v5i1
\begin{tabular}{|l|l|l|}
\hline Submission: January 28, 2021 & Revised : July 21, 2021 & Published : June 30, 2021 \\
\hline
\end{tabular}

\begin{abstract}
A complex issue that is very difficult to unravel in the Minangkabau community is about communal land as a high inheritance according to Minangkabau customs. In Minangkabau custom, the land is women's right, but in control and who takes the lead to maintain land tend to cause dispute between men and women in its development and utilization. High inheritance assets that women should own should be fully controlled and utilized by the brothers. Meanwhile, women must be willing to leave the clan to find residential or agricultural land. This problem becomes more acute when economic problems and social stratification are carried away in the dialogue. Often the rights that women should naturally receive in Minangkabau are crippled by gender stratification developed by brothers who feel more powerful and feel physically and economically stronger.
\end{abstract}

Keywords: Human Rights, Adat, Dispute, Communal land.

\begin{abstract}
Abstrak
Persoalan pelik yang sangat susab diurai dalam masyarakat Minangkabau adalah persoalan tanah ulayat sebagai harta pusaka tinggi menurut adat Minangkabau. Dalam adat Minangkabau, tanah adalah bak perempuan, namun dalam pengawasaan dan penguasaan sering kali timbul silang sengketa antara laki-laki dan perempuan dalam penguasaan dan pemanfaatannya. Harta pusaka tinggi yang seyogyanya dimililiki oleh perempuan dikuasai dan dimanfaatkan secara penub oleh saudara laki-laki. Sementara perempuan harus rela keluar dari kaum untuk mencari lahan pemukiman atau pertanian. Persoalan ini semakin meruncing ketika persoalan ekonomi dan kekuatan stratifikasi sosial terbawa dalam dialog tersebut. Sering kali bak yang seharusnya diterima perempuan secara asasi di Minangkabau terkebiri oleh strafikasi gender yang dikembangkan oleh saudara laki-laki yang merasa lebih berkuasa dan merasa lebih kuat secara fisik dan ekonomi.
\end{abstract}

Kata kunci : HAM, Adat, Sengketa, Tanah ulayat.

\section{Introduction}

Thoughts on fundamental rights called Human Rights have emerged since human birth. However, human rights are often associated with the conflict between universalism and the theory of cultural relativism. The theory of universalism views that humans have rights that arise naturally without any role or intervention from other parties that arise by themselves without being put forward by others. Universal rights will be born along with the birth of humans as one of the souls in society. Whereas the theory of cultural relativism assumes that human rights come from law, rights can never exist without governing laws. The 
view of cultural relativism emerged as a response to the imposition of universal human rights. ${ }^{1}$

The theory of cultural relativism is often associated with maintaining the status quo of its power in society. Rhona K.M. Smith, as quoted by Nur AfifArdani, stated that in cultural relativism, an idea would be more or less forced because the various cultures that exist conflict with those in power. Often a group rejects the rights of other groups that occur in the interests of the group itself. Thus, human rights cannot be utterly universal unless human rights are not subject to local cultural provisions that have been made unanimously and used for generations and thus cannot represent every individual. $^{2}$

Indonesia consists of various cultures that are embraced and held by its people. One of the cultures that exist in the archipelago is Minangkabau as one of the cultures of the tribes that inhabit most of Central Sumatra. Minangkabau tribe is known as a tribe who likes to wander, so "urang Minang" is spread throughout the archipelago; even almost to five continents. The Minangkabau tribe is also famous for its inherent culture. The culture found in the Minangkabau tribe is unique and distinctive, which can be observed through the

${ }^{1}$ Deklarasi Universal HakAsasiManusia yang ditandatangani oleh 48 negara pada tanggal 10 Desember 1948 di Paris, Perancis, menjadi tonggak bersejarah bagi universalisme Hak Asasi Manusia. Setiap manusia di dunia, memiliki hak yang sama, siapapun dia dan apapun dia. Sampai saat ini, tanggal 10 Desember diperingati sebagai Hak Asasi Manusia. Negara-negara yang belum menandatangani deklarasi ini "dianggap" sebagai negara yang tidak mendukung penegakan Hak Asasi Manusia, bahkan ada Negara yang diberi sanksi seperti embargo ekonomi karena dianggap telah melanggar Hak Asasi Manusia. Lihat; Nur Afif Ardani, dkk," "Relativisme Budaya Dalam Hak Asasi Manusia", Jurnal Cakrawala Hukum, Vol. XIV No. 1, Tahun 2017, h. 30-31

IIbid., h. 33 matrilineal lineage it adheres to. This contrasts with other tribes in the archipelago, which predominantly adhere to patrilineal lineages or are based on father's lineage. This difference seems to illustrate the determination of the ancestors of the Minangkabau people to determine lineage based on the mother's lineage. ${ }^{3}$ The dominant role of women in Minangkabau culture depicts a highly exalted position for women as a characteristic that distinguishes Minangkabau from other regions in Indonesia. In Minangkabau society, women are depicted as decorations for the Nagari (limpapeh Rumah nan gadang). The Minangkabau matrilineal kinship system places women as heirs to wealth and men as the party who moves to women's homes. This position not only acts as a symbol but is given a role according to that position in society. Therefore, Minangkabau women in adat have a place in decision-making in every deliberation held in the Nagari. ${ }^{4}$

Minangkabau men have two norms that contain different responsibilities that have their own consequences. Minangkabau men (Mamak) experience inner conflict, on the one hand as guardians and supervisors of nephews and inheritance according to custom; on the other hand, the desire to control their children according to instinctive impulses are contrary to custom. Even though, in practice, Mamak prioritizes their own children in the supervision of their nephew's children, the concept of an ideal role that is instilled in culture creates an uncomfortable feeling when Mamak is

${ }^{3}$ Arif Setiawan, Sistem Kekerabatan Matrilineal dalam Adat Minangkabau Pada Novel Siti Nurbaya: Kasih Tak Sampai Karya Marah Rusli, Jurnal Alfabeta Vol.2, Nomor 1, April 2019, h. 93

${ }^{4}$ Ibid., h. 94 
unable to fulfill social expectations for her role in adat. ${ }^{5}$

One of the thorny issues that are very difficult to unravel in Minangkabau society is the issue of communal land as a high inheritance according to Minangkabau custom. In Minangkabau custom, land is the right of women, but in the supervision and control, disputes often arise between men and women in the rights and use of it. High heirloom assets that women should own are controlled and fully utilized by brothers. Meanwhile, women must be willing to leave their families in search of residential or agricultural land.

This issue is exacerbated when economic issues and the power of social stratification are brought into the dialogue. Often, the rights women should receive as human rights in Minangkabau are negated by gender stratification developed by brothers who feel more powerful and feel physically and economically stronger.

\section{Discussion}

\section{Matrilineal and Communal Land in Minangkabau}

Minangkabau is a community group that firmly adheres to the matrilineal kinship system, namely kinship with lineage based on the mother's line. Matrilineal consists of 2 (two) syllables "matri" meaning (mother)

${ }^{5}$ Situasi ini dikenal dengan istilah "matrilineal puzzle", yaitusituasi di mana seorang laki-laki memiliki dua tanggung jawab pada rumah asalnya (rumah ibu, saudari perempuan dan kemenakannya) dan rumah istrinya (rumahnya bersama istri dan anak-anak kandungnya). Matrilineal puzzle dapat memicu konflik dalam diri laki-laki ketika sumberdaya yang dimilikinya terbatas, sehingga ia harus menetapkan prioritas antara memenuhi kebutuhan anak kandung atau kemenakannya. Lihat; Niken Hartati, Apakah system kekerabatan matrilinieal di suku Minang masih membudaya? Analisi stematik pada makna pemberian dukungan social mamak kepada kemenakan, Jurnal Psikologi Sosial, 2020, Vol. 18, No. 03, h. 202 and "lineal" (line), so it means "mother line"; so that matrilineal is understood as a term for a kinship system that refers to the mother's lineage. A person's tribe according to Minangkabau custom will follow his mother's tribe. Women have a special position in the race, and tribe members may not marry; and the party controlling the inheritance is the mother as the ties of kinship in the Rumahgadang concerning heirlooms and sako (titles). ${ }^{6}$

The oldest woman in a tribe in Minangkabau culture will be called the limpapeh or amban puruak. This title is a form of respect for the control of all the people's assets, and he has the right to regulate the distribution of assets. The oldest man in the clan is dubbed the term tungganai who serves as Mamak Kapalo Warih. Tungganai's task is to maintain, cultivate, and develop people's property, but not to use the property.

The term limpapeb ${ }^{8}$ in rumah gadang produces the concept of bundo kanduang ${ }^{9}$ as a

${ }^{6}$ Iva Ariani, Nilai Filosofis Budaya Matrilineal di Minangkabau (Relevansinya bagi Pengembangan Hak-hak Perempuan di Indonesia), Jurnal Filsafat, Vol. 25, No. 1, Februari 2015, h. 37

7 Ibid., h. 36

8Peran yang dimainkan oleh kaum perempuan di Minangkabau baik sebagai istri maupun ibu dari anak-anak banyak dilibatkan pada tugas-tugas yang domestik, yang dikenal dengan istilah limpapeh rumah nan gadang, unduang-unduang kasarugo, turun nan kasakali sajo maik, karajo manyulam nan jo manjaik di ateh anjuang, bahkan sampai bentuk tugasnya melebihi laki-laki. Dalam teori kekerabatan adanya sistem kekerabatan matrilinial yang didukung oleh adat basandi syarak, syarakat basandi kitabullah.

${ }^{9}$ Sesuai perkembangan zaman bundo kanduang menjadi lembaga atau wadah bagi perempuan yang memfungsikan dirinya dan berperan aktif dalam kegiatan anak nagari. Bundo kanduang merupakan panggilan untuk perempuan Minangkabau, tetapi sebuah wadah bagi perempuan Minangkabau dalam memahami keberadaansebagai sumarak nagari dan pelanjut warisan serta menyadari tentang harkat dan fungsi ditengah konstelasi adat dan budaya terutama 
female character who places women in a very central position, as the ruler of heirlooms that can be used as social security and protectors from various household economic problems faced by family members. ${ }^{10}$

Bundokanduang in Minangkabau society who adheres to matrilineal culture is the embodiment and symbol of pride and glory in determining lineage. The position of women as bundokanduang makes her a respected and respected party. This position also makes Minangkabau women have to have feminine, motherly traits and do work that does not burden them. ${ }^{11}$ Minangkabau women are accustomed to being strong and proficient in sewing and embroidery. So Minang women must be good at making household jewelry, such as various kinds of flowers, wall hangings of cloth, silk, and velvet; and they are also good at making room and bed decorations with flower decorations or other forms of decoration. Some can also make clothing decorations, such as clothes, scarves, head coverings, handkerchiefs, belts, cigarette holders, children's hats, and others. Of course, with different subtle and rough as well. ${ }^{12}$

dalam menghadapi berbagai perubahan dan tantangan masa depan. Kelompok perempuan di Minangkabau di bawah organisasi bundo kanduang jauh berbeda baik dalam gerak langkah maupun program pelaksanaan dan memutuskan suatu perkara

10 Ellies Sukmawati, Filosofi Sistem Kekerabatan Matrilineal sebagai Perlindungan Sosial Keluarga pada Masyarakat Minangkabau, Empati (Jurnal Ilmu Kesejahteraan Sosial), Vol. 8 No. 1 Juni 2019, h. 20-26

11 Raudhatul Jannah, Potret Perempuan Pekerja Batu Bata di Jorong Turawan Nagari III Koto Kecamatan Rambatan Kab. Tanah Datar (Perspektif Sosiologis dan Hukum Ekonomi), Jurnal Humanisma: Journal of Gender Studies, Vol. 2, No. 1, Januari-Juni 2018, hal. 41

12 Nurafrida Deliani, et.all., Gerakan Emansipasi Ruhana Kuddus dalam Memperjuangkan Keseteraan Pendidikan Perempaun di Minangkabau,
However, in reality, the increasingly high demands of life make women indeed have to share the family's economic burden. Urgent economic needs can break traditions and gender views that have been firmly entrenched in society. Even the pressing economic burden has forced a bundokanduang as a woman who was originally only a housewife to become a woman who works outside the home with various very challenging.

The power of women in Minangkabau customs through traditional symbols has become a debate among social science circles, so it needs to be re-translated appropriately and correctly to revitalize the position, duties, functions, and existence of all women in Minangkabau customs. When viewed from matrilineal customs, the status and role of Minangkabau women creates a dilemma; on the side of their relatives and people, women have high status and are respected and even this role can also cause discrimination for men because there is an imbalance between the obligations and rights they carry. Obligations of Minangkabau women as the lifeline of clan members; in the form of a place to live and manage agricultural land known as heirlooms. Meanwhile, on the other hand, Minangkabau women will be at the forefront and at the forefront of family, clan and nation issues, because women are obliged to integrate and be pro-active with all issues and problems of society and actualize them limpapeh Rumah nan Gadang, induang-induang ka sarugo. ${ }^{13}$

The welfare of a family is influenced by economic conditions that shape the family's resilience in meeting economic

Jurnal Humanisma : Journal of Gender Studies, Vol. 3, No. 2, Juli-Desember 2019, hal. 173

13 Sri Yunarti, Inisiasi Posisi dan Peran Perempuan dalam Konteks Budaya Minangkabau,Jurnal Humanisma : Journal of Gender Studies, Vol. 2, No. 1, Januari-Juni 2018, hal. 29 
needs, so that if a family experiences economic incapacity, it will have a direct impact on the poverty condition of the family. Anticipatory efforts needed to prevent families from poverty are carried out through social protection. An important means to alleviate the impact of poverty and destitution faced by families is based on 4 (four) main components, namely employment, social security, social insurance, and local-based protection patterns. ${ }^{14}$ Of the four components mentioned above, the pattern of local-based protection is directly related to heritage land (baratopusako) as the basis for family farming. Thus, the Minangkabau custom which adheres to a matrilineal system that positions women in tough positions and roles. On the one hand, women will be respected as leaders in their relatives, and have a burdensome and responsible task in the socio-economic life of family members; including in terms of economic fulfillment, maintaining security, and maintaining the continuity of customs including the preservation of sako and pusako (communal land).

In general, humans and land have an intertwined relationship, especially in terms of economy and production, as J.B.A.F Polak quoted by DjamatSamosir stated that the relationship between humans and land was originally occupation as a basis for efforts to become a source of livelihood. ${ }^{15}$ Thus, juridical control and ownership of land requires legal recognition and protection, which has implications for civil rights of land ownership and fair treatment of ownership. The process of legal certainty of land ownership requires land

\footnotetext{
${ }^{14}$ Ellies Sukmawati, Filosofi Sistem, op. cit., h.
} 20-26

${ }^{15}$ Djamanat Samosir, Hukum Adat Indonesia, Eksistensi dalam Dinamika Pembangunan Hukum di Indonesia, (Bandung: C.V. NuansaAulia, 2013), h. 97 registration as regulated in the Basic Agrarian Law through land registration in providing legal certainty and legal protection to the holder of rights to a plot of land and other rights contained therein; making it easier to prove someone is a fitting holder. ${ }^{16}$

The relationship between land and humans in the culture and customs of Minangkabau (West Sumatra) is unique, when some of the existing land is communal land that functions socially based on the principle of kinship and is used for the needs of its people. Communal land is a constitutive condition regarding the existence of a group of indigenous peoples. Recognition of customary land tenure is the main agenda of the indigenous people movement in Indonesia or the world. communal land is obtained from generation to generation from ancestors and passed down from generation to generation; communal land in Minangkabau (West Sumatra) is often a problem in terms of ownership by the next generation due to the control of the land. In the view of customary law, communal land should not be divided as joint property and its ownership should not be divided up or made into private property. ${ }^{17}$

Every Nagari in West Sumatra has its own communal with boundaries according to the situation and natural conditions, such as hills, rivers or rice fields. The area of the Nagari area is never the same from one another, depending on the abilities of the ancestors of the manaruko Nagari; or one's ability to travel, perhaps to the top of a hill, a steep cliff, a rushing river or an impenetrable wilderness. The impenetrable area is called

16 Boedi Harsono, Hukum Agraria Indonesia Sejarah Pembentukan Undang-Undang Pokok Agrariaisi dan pelaksanaannya, (Jakarta: Djembatan, 2005), h. 470

${ }^{17}$ AA. Navis, Alam Terkembang Jadi Guru, (Jakarta: Graffiti Pers, 1984), h. 134 
lareh forest, meaning loose forest that has no inhabitants. ${ }^{18}$

A. A Navis stated that there are 2 (two) types of communal in one Nagari, namely: communal Nagari and communal clan. The Nagari communal is a forest that has become a nature reserve and a Nagari reserve land, which is also known as a high forest. It is under the authority of the andiko penghulu called the head of the four tribes in the Nagari. Meanwhile, customary land can be used but has not been processed by the community, which is commonly called lowland forest. This communal property is under the authority of the tribal leader in his people. $^{19}$

The main target of using communal land is to seek to improve the welfare and prosperity of indigenous peoples. Utilization of communal land is carried out with the principle of mutual benefit and risk-sharing with the method of "adat diisi limbago dituang" or deciding based on the prevailing custom through deliberation and consensus within the community.

The existence of communal land is recognized by the Basic Agrarian Law, Article 3 that the implementation of communal rights and similar rights of customary law communities as long as they are in accordance with national and state interests and may not conflict with higher laws and regulations. This rule is also emphasized by Article 5 which states that the agrarian law applicable to earth, water and space is customary law. As long as it does not conflict with national and state interests based on national unity with Indonesian socialism and the regulations contained in this law and with other laws and regulations, everything with due regard

\footnotetext{
${ }^{18}$ AA. Navis, AlamTerkembang; op. cit., h. 151

${ }^{19}$ Ibid. h. 152
}

to elements that rely on religious law. ${ }^{20}$

In the Minangkabau customary community, there are three basic types of land tenure, namely group or Nagari control, communal and individual or private control. The control over land in the Minangkabau community is also regulated in customary regulations that are maintained and obeyed from generation to generation and implemented by the community. Conflicts or disputes caused by land will be resolved by customary regulations that exist in the community through customary law that applies to the mutuality of Nagari customs and is based on deliberation and consensus. $^{21}$

As one part of the many ethnic groups that inhabit the Indonesian archipelago, the Minangkabau people live in an environment of customary law with specific characteristics that distinguish them from other customary law communities in Indonesia. While the legal relationship between the community and the land creates a right to use, control and defend that right. The female lineage or bundo kanduang in Minangkabau society which adheres to the matrilineal system creates a traditional system of inheritance (pusako) land tenure based on inheritance to daughters. Men function as supervisors or protectors of land rights from various unwanted things and can cause the loss or reduction of inheritance. Land in Minangkabau society as wealth shows the authority of a people which is determined by the extent of the land owned. In addition,

${ }^{20}$ Undang-Undang Republik Indonesia Nomor 5 Tahun 1960 tentang Peraturan Dasar Pokok-Pokok Agraria

${ }^{21}$ Ketentuan ini terungkap dalam fatwa adat yang menyatakan "Bulek aia karano pambuluah, bulek kato dek mufakat" (bulat air karena pembuluh, bulat kata karena mufakat). Maksudnya lebih mengutamakan pola musyawarah mufakat dalam pengambilan keputusan. Lihat; AA. Navis, Alam Terkembang; op. cit., h. 136 
ownership of pusakoland will determine whether or not a person in a clan belongs to a communal area. ${ }^{22}$

The Minangkabau custom also outlines the exception to this inheritance. It shows by the ability to pawn as long as it does not deviate from the "pusako salingka Suku" provisions. The point is that communal land (inheritance) may be mortgaged to tribal members to meet the specified requirements. The provisions in question are first, Pertama, gadih gadang indak balaki (a girl who is an adult and deserves to be married, but not yet married) or rando dapek malu (a widow who gets embarrassed or is a victim of slander in society). The process of pawning for inheritance can be carried out to marry the adult niece or widow. The second provision is Rumah Gadang katirisan (the condition of the large (main) house that is leaking or damaged). The pawning process can also be done to repair the main house of the family concerned. The third stipulation is mambangkik Batang tarandam (reviving a submerged trunk or a clan heirloom title that has not been revived for a long time). The pawning process can be carried out to revive the title of Penghulu, which has not been used for a long time. The fourth provision, mayiek tabujua di tanga brumab (a dead body lying on a house and waiting for funds to be buried). Pawns can be made for the funeral of the deceased member of the clan.

Communal land in Minangkabau in the form of residential land, rice fields, fields, forests, rivers, and mining products is simply referred to in the term "harato

${ }^{22} \mathrm{Hal}$ ini sesuai dengan fatwa adat yang menyatakan" bahwa asli atau tidaknya seseorang atau suatu kaum berasal dari suatu daerah harus ditandai dengan: Ado tapian tampek mandi, Ado basasok bajarami, Ado bapandan bapakuburan. Lihat; AA. Navis, Alam Terkembang; op. cit., h. 146 pusako". Grammatically, the meaning of pusako is heirloom which contains the understanding that wealth is inherited from generation to generation by heirs in the maternal line. The basic principle of ownership of pusako property is communal or jointly; no member of the Minangkabau community can prove their individual (private) ownership of a plot of communal land. ${ }^{23}$

The changing conditions of society and the demands of the times have also made various individual demands as citizens in their society. The ideal rule of land ownership as harato pusako, which descends in the maternal lineage often deviates from the actual line. Economic demands and social stratification in society and the strong male character make gender castration of the right to receive harato pusako in the form of land in Minangkabau. Cases of reducing and even eliminating ownership rights for girls in several Nagari in Minangkabau located within the City's administrative area have occurred. Changes in indigenous peoples' mindset in urban administration also require the issuance of certificates for their customary land ownership.

Economic demands on the one hand and social stratification are the two things that cause inequality in the acceptance of harato pusako in rural-urban communities. The case for a girl who lives overseas in a weak condition economically causes her to be abandoned by other relatives in possession of harato pusako. It is where inequality occurs. Communal land, which is ideal as a support for the family's economy turns into contested land. The social trap that occurs is the law of the jungle with the rule that the party who feels materially strong and social status will become the ruler rather than the weak and low social

${ }^{23}$ Ibid, h. 147 
stratification.

An interesting case of communal land in an urban area is that of a brother who builds a house on high pusako land. This happened because her sister did not live in her communal environment, so the mamak freely controlled the land to build a house for his wife and children on his mother's communalland. Similar cases often occur on communallands within the City's administrative area; Due to the high price of residential land, the brother (Mamak) acts to sell, control, or allocate land for his wife and children. Although this is very much against the rules of Minangkabau customs, the power of social stratification seems to make the adage "the strong becomes the winner" in society.

If viewed from the point of view of Human Rights, then there has been a violation there; This means that the rights that are actually obtained from generation to generation by women have been taken at will by brothers (Mamak) to be given to their children and wives. Meanwhile, the teachings about communal land in Minangkabau are: " airnya boleb diminum, buabnya boleh dimakan, tanabnya tetaptinggal". Communal land may not be transferred to other parties; dijua indak dimakan jua, digadai indak dimakan sando. Communal land is declared an expensive property that cannot be bought, cheap, or asked for. ${ }^{24}$

According to the Regulation of the State Minister of Agrarian Affairs/Head of the National Land Agency No. 5 of 1999 concerning guidelines for resolving the problem of customary rights of customary law communities. What is meant by customary rights is the authority which according to customary law is owned by certain customary law communities over

${ }^{24}$ Dt. Parapatiah Nan Tuo; AdatBasandiSyara, SyarakbasandiKitabullah, PedomanbidupBanagari, SakoBatuah, (Padang: tt, t.th), h. 80-81 certain areas which are the living environment of their citizens to take advantage of natural resources, including land within the territory, for the survival and life arising from outward and inward relationships that are hereditary and unbroken between the customary law community and the territory concerned. ${ }^{25}$

Meanwhile, in the Regional Regulation Number 16 of 2008 concerning Communal Land and Its Utilization, land tenure in the Minangkabau customary law community is regulated as follows:

a. Nagari communal land is communal land along with the natural resources that exist above and in it is the right of control by the ninik Mamak of the Kerapatan Adat Nagari (KAN) and is utilized as much as possible for the benefit of the Nagari community, while the Nagari government acts as the party that regulates its utilization.

b. Communal land is the ownership rights to a plot of land along with natural resources that are above and in it is the collective property of all members of a certain tribe whose control and tribal leaders regulate utilization.

c. Communal land it is a property right to a plot of land along with the natural resources above, and in it is the property of all members of the clan consisting of the jurai/paruik whose control and utilization is regulated by the Mamak jurai/Mamak of the head of the heirs.

d. Communal land Rajo is the ownership right to a piece of land and the natural resources above and within it, the control and utilization regulated by the eldest

${ }^{25}$ Peraturan Menteri Negara Agraria/Kepala Badan Pertanahan Nasional No. 5 Tahun 1999 tentangPedomanPenyelesaianMasalahHakUlayat Masyarakat Hukum Adat 
male from the mother's lineage who currently lives in several Nagari in West Sumatra Province. ${ }^{26}$

Customary land of the Nagari is under the supervision of the penghulu in the Kerapatan Adat Nagari as joint property of the people in the Nagari. Nagari communal land can be in the form of forest, shrubs, or land that is within the scope and management of the Nagari. Nagari is a combination of koto, which has a tribe and occupies a certain area. In general, a Nagari consists of 4 (four) tribes and is led by a Nagari guardian who is determined based on elections based on deliberation and consensus between elements in the Nagari community (tali Tigo sapilin ataupun Tigo tungku sajarangan). Nagari communal land is used for general purposes, such as constructing mosques, constructing traditional halls, and markets or other interests that can be utilized for the common good.

Tribal communal lands are held by tribal leaders and managed by tribal members. Tribe is a combination of several tribes, where the blood ties that bind the tribe are blood ties according to the mother's line. Meanwhile, communal lands are lands that the people jointly manage as Pusako Tinggi assets, which are used for the welfare of the nephew's children, especially to meet their economic needs. The people's customary land is owned communally as property which is given the right to members of the tribe to collect the results.

If there is a customary land dispute, the settlement that must be taken is through customary institutions that exist in the Minangkabau community, starting from a lower level to a higher level, as confirmed in Article 12 of Regional Regulation No. 16 of

26Peraturan Daerah Nomor 16 Tahun 2008 tentang Tanah Ulayat dan Pemanfaatannya
2008 concerning Communal Land and its Utilization. namely: "Ultimate land disputes in the Nagari are resolved by the Kerapatan Adat Nagari according to the provisions as long as the customs apply, bajanjang naiak bertanggo turun and strive to deal with the problem peacefully". ${ }^{27}$

Kerapatan Adat Nagari carries out cross dispute settlement of customary land disputes in a Nagari, which is carried out at the Customary Hall by a panel of judges determined by the penghulu. The settlement of this dispute is carried out by deliberation and consensus as expressed in the customary fatwa which reads: bulek aia dek pambuluah, bulek Kato desk mufakat, ${ }^{28}$ and dealing with problem by saying bajanjang naik batanggo turun. ${ }^{29}$ The evidentiary process in making a dispute resolution decision is one of the most decisive elements in the trial. So that in this process the parties have the opportunity to submit evidence with supporting evidence, both written documentation in the form of letters, or witness statements and other evidence as reinforcement The evidentiary process in making a dispute resolution decision is one of the most

${ }^{27}$ Peraturan Daerah Nomor 16 Tahun 2008 tentang Tanah Ulayat dan Pemanfaatannya

${ }^{28}$ Sejenis saluran air yang berasal dari bambu dan bulat kata karena musyawarah atau mufakat

${ }^{29}$ Sengketa tanah ulayat yang terjadi dalam masyarakat Minangkabau artinya terlebih dahulu diselesaikan melalui lembaga adat pada tingkat yang lebih rendah yaitu tingkat keluarga kemudian ketingkat kampung dan terakhir tingkat nagari. Sedangkan batanggo turun berarti hasil penyelesaian sengketa pada masing-masing tingkat diharapkan akan dipatuhi oleh pihak yang bersengketa sebab yang menyelesaikan itu adalah orang yang telah dituakan dalam kaum atau nagari sehingga pihak yang bersengketa tidak bias menolaknya. Jika terjadi sengketa dalam keluarga yang diselesaikan oleh mamak dalam keluarga; jika tidak dapat diselesaikan pada tingkat keluarga, maka diselesaikan oleh penghulu paruik dalam persekutuan; jika belum juga selesai maka dilanjutkan ke Kerapatan Adat Nagari (KAN). 
decisive elements in the trial; so that in this process the parties have the opportunity to submit evidence with supporting evidence, both written documentation in the form of letters, or witness statements and other evidence as reinforcement.

\section{Local Government Policies in Defending Women's Rights}

Disputes over communal land within clan members or saparuik occur because of the unequal distribution of communal land by the Mamak of the head of the heirs to clan members with the term ganggam bauntuak. Gangnam bauntuak from high pusako property or communal land is given by Mamak to members of the clan to be utilized and cultivated so as to produce economically in financing their family life.

Disputes in clan members can occur because of the issue of commensurate land boundaries owned by clan members with other clan members. This equivalence boundary may exist between members of the same clan; or between members of one race and another. One example of a commensurate dispute is moving the boundary that the head of the inheritance has set due to moving the equivalence boundary of saparuik (clan) so that it uses the rights of another paruik (clan) because a person (clan) first works on the land that has been given ganggam bauntuak from the mamak head, inheritance; while a clan that has not worked on its share will be disadvantaged because it has switched to the equivalent limit set by Mamak in the previous ganggam bauntuak. When the uncultivated paruik (clan) sees its part of the land already being worked on or taken by the cultivating clan (clan) by moving the commensurate limit which the heir's Mamak has determined; there will be a dispute between members of the clan over the sense of ownership of the land. The head of the inheritance resolves problems like this by means of deliberation between the members of the paruik (clan) both those who are in dispute and those who are not involved in the dispute so that all members of the paruik (clan) know the limits of their respective shares.

Before the deliberation with the paruik (clan) members, the head of the heirs first saw the disputed land. Before deciding, a peace effort is made between the disputing parties by summoning the disputing parties and offering whether both parties are willing to make peace by resolving the two disputed issues. If the mamak head of the heirs decides that each one who controls or cultivates the land. That has been obtained with a limit determined by the Mamak of the head of the heirs is not allowed to take the other members of the parnik by returning the costs that have been incurred by those who cultivate the land of other members of the clan. After the decision is made, the respective heads of heirs who are in the dispute will sign the decision letter, while the other members will also sign as witnesses.

The regulation of the Governor of West Sumatra related to the customary land of the people in Chapter III Article 5 paragraph (3) reads "The customary land of the people as referred to in article 4 letter $\mathrm{c}$ is domiciled as arable land with the status of ganggam bauntuak pagang bamansiang by members of the clan whose control and ninik mamak kapalo heirs carry out regulation following Minangkabau customary law". ${ }^{30}$ Likewise with the provisions of Article 4 in the Regional Regulation of the Province of West Sumatra Number 16 of 2008 it is also stated that "The purpose of regulating communal land

${ }^{30}$ Peraturan Gubernur Sumatera Barat Nomor 21 Tahun 2012 
and its use is to continue to protect the existence of communal land according to Minangkabau customary law and to take advantage of the land, including natural resources, for survival. and their lives are hereditary and uninterrupted between the customary law community and the territory concerned". ${ }^{31}$

In the two articles above, it has implicitly hinted that the use of communal land is the right of women, the old pusako custom also reinforces this in every Nagari in Minangkabau which stipulates that it is women who cultivate and have the right to communal land for their economic interests. This Governor Regulation is very prowomen as the authority holder of customary ownership rights over land; but cases of castration of the rights received by women still occur in the local community.

An obvious provision is contained in Article 2 of the Regional Regulation of West Sumatra Number 16 of 2008 which reads (1) The main principle of communal land is permanent based on the Minangkabau traditional philosophy of 'juandak. Makan bali, gadai ndak makan sando'; (2) The principle of utilization of communal land is the maximum benefit for the benefit of indigenous peoples, justice and responsibility following the philosophy of Adat Basandi Syara'; Syara' Basandi Kitabullah; (3) The Unilateral principle which is the inheritance right of communal land that applies in a kinship according to the mother's lineage. ${ }^{32}$ The third paragraph of Article 2 explicitly states that the inheritance rights of communal land are valid in Minangkabau adat with a kinship system according to maternal lineage. Such assertiveness makes the position of women as holders of the

\footnotetext{
${ }^{31}$ Peraturan Daerah Nomor 16 Tahun 2008 tentang Tanah Ulayat dan Pemanfaatannya

32Peraturan Daerah Nomor 16 Tahun 2008 tentang Tanah Ulayat dan Pemanfaatannya
}

economic use rights of customary land cannot be transferred to other parties.

Settlement of customary land disputes that occur within the Minangkabau customary community is regulated in article 23 which states that: (1) Disputes that occur in the use of customary land for investment are resolved by deliberation and consensus to reach an agreement directly through negotiations; (2) In the event that consensus is not reached, the dispute resolution as referred to in paragraph (1) can be carried out with the assistance of the Nagari government, KAN, LKAAM, Camat, regional government and other independent third parties as mediators to mediate the dispute. (3) In the event that the mediation as referred to in paragraph (2) is not achieved, the dispute resolution can be carried out through arbitration in accordance with the provisions of the laws and regulations. (4) Settlement of disputes as referred to in paragraph (1), paragraph (2) and paragraph (3) does not rule out the possibility of investors and owners or rulers of customary lands to settle their disputes through the local district court in accordance with the provisions of the legislation. ${ }^{33}$

The implications of the various regulations formulated by the Regional Government of West Sumatra Province regarding communal lands were responded positively by ninik Mamak, Nagari government officials, academics, activists, and observers of Minangkabau customs. In many Nagari in the Minangkabau realm, awareness has begun to return to tracing the inheritance (communal) of their respective people as the basis of their mother's family life.

The pandemic era is also one of the factors to rekindle positive efforts towards

33 Peraturan Gubernur Sumatera Barat Nomor 21 Tahun 2012 
returning inheritance to the mother's family to be used as an economic base for the family (see sisters and nieces). In various Nagari in West Sumatra, many migrants return to their hometowns due to limited work in overseas lands. High Pusako land is an alternative for them to fight for their family's economic needs through farming activities. Automatically the need for agricultural land is increasing compared to the previous period.

The positive impact of various regulations set by the West Sumatra Regional Government, of course, also has an impact on the positive development of the family economy, which incidentally greatly affects the position of women in the household. Lack of agricultural land in one clan, for example, will force a sister to look for alternative agricultural land other than her clan's inheritance through manya duo transactions for other people's agricultural land. Apart from that, they can also carry out economic activities in the service sector, such as trading, coolies, or technical fields that require special skills (mechanics, craftsmen, and others.

The position of women and inheritance are intertwined with the position in the Nagari. A tribe can be proven to be a native occupier (usali) with people's property. (parak babintalak; sawah bapamantang; bapandam bapakuburan). The decision to own the inheritance will harm women and their offspring to be threatened from being accused of being immigrants; because they no longer have the original wealth that has been passed down from generation to generation.

The efforts made by the adat community (ninik Mamak) are a refresher for the tribal leaders to re-investigate the ownership of heirlooms for each tribe. The activity is usually in the form of sharing for the ninik Mamak of the tribal chief about various rules to remind each other for the continuity of the people's customary rights. In addition, the ninik Mamak also revived the boundaries of the Nagari as an effort to seek the communal rights of the Nagari. Nagari forests are empowered for the welfare of the Nagari community to support the family economy. Of course, the family economy greatly affects the position of women in the household as the limpapeh Rumah nan gadang.

\section{Conclusion}

The description above explains that the settlement of communal land disputes is carried out through the bajanjang naik batanggo turun mechanism; namely dispute resolution starting from the lowest institutional level by Mamak Kapalo Warih (paruik), Mamak tribes and tribal leaders. If an agreement is not obtained, then proceed to a higher customary institution, namely the Kerapatan Adat Nagari (KAN). The process of settling customary land in Minangkabau is in the following order:

1. Disputes over members of the saparuik are resolved by the mamak kapalo warih (paruik);

2. Customary land disputes within the tribe are resolved by the tribal chief;

3. Customary land disputes that cannot be resolved at the lowest customary institution will be resolved by the Kerapatan Adat Nagari (KAN);

Settlement of communal land through customary institutions in the Nagari by both lower and higher customary institutions is quite effective. This is because customary institutions are carried out through deliberation and prioritize the principle of justice for the litigants.

The provisions that the government of West Sumatra Province has formulated gave 
birth to various policies to defend the position of women in order to maintain the kinship system. All kinds of policies created by the West Sumatra Regional Government to maintain their existence adat basandi syara' and syara' basandi kitabullab for matrilineal interests.

\section{Bibliography}

\section{Journal}

Ardani, Nur Afif, dkk," "Relativisme Budaya Dalam Hak Asasi Manusia". Jurnal Cakrawala Hukum, Vol. XIV No. 1, Tahun 2017.

Ariani, Iva, Nilai Filosofis Budaya Matrilineal di Minangkabau Relevansinya bagi Pengembangan Hak-hak Perempuan di Indonesia). Jurnal Filsafat, Vol. 25, No. 1, Februari 2015, h. 37.

Deliani, Nurafrida, et.all., Gerakan Emansipasi Rubana Kuddus dalam Memperjuangkan Keseteraan Pendidikan Perempaun di Minangkabau. Jurnal Humanisma : Journal of Gender Studies, Vol. 3, No. 2, Juli - Desember 2019

Hartati, Niken, Apakah system kekerabatan matrilinieal di suku Minang masib membudaya? Analisi stematik pada makna pemberian dukungan social mamak kepada kemenakan. Jurnal Psikologi Sosial, 2020, Vol. 18, No. 03.

Jannah, Raudhatul, Potret Perempuan Pekerja Batu Bata di Jorong Turawan Nagari III Koto Kecamatan Rambatan Kab. Tanah Datar Perspektif Sosiologis dan Hukum Ekonomi). Jurnal Humanisma : Journal of Gender Studies, Vol. 2, No. 1, Januari - Juni 2018

Setiawan, Arif, Sistem Kekerabatan Matrilineal dalamAdat Minangkeabau Pada Novel Siti Nurbaya: Kasib Tak Sampai Karya Marah Rusli, Jurnal Alfabeta Vol.2, Nomor 1, April 2019.

Sukmawati, Ellies, Filosofi Sistem Kekerabatan Matrilineal sebagai Perlindungan Sosial Keluarga pada Masyarakat
Minangkabau. Empati (Jurnal Ilmu Kesejahteraan Sosial), Vol. 8 No. 1 Juni 2019, h. 20-26

\section{Books}

Harsono, Boedi, Hukum Agraria Indonesia Sejarah Pembentukan Undang-Undang Pokok Agrariaisi dan pelaksanaannya, Jakarta: Djembatan, 2005.

Navis, AA., Alam Terkembang Jadi Guru, Jakarta: Graffiti Pers, 1984.

Samosir, Djamanat, Hukum Adat Indonesia, Ekesistensi dalam Dinamika Pembangunan Hukum di Indonesia. Bandung: C.V. Nuansa Aulia, 2013.

\section{Article and regulation}

Dt. Parapatiah Nan Tuo; Adat Basandi Syara, Syarak basandi Kitabullah, Pedoman bidup Banagari, Sako Batuah, Padang: tt, t.th.

Peraturan Daerah Nomor 16 Tahun 2008 tentang Tanah Ulayat dan Pemanfaatannya.

Peraturan Gubernur Sumatera Barat Nomor 21 Tahun 2012.

Peraturan Menteri Negara Agraria/Kepala Badan Pertanahan Nasional No. 5 Tahun 1999 tentang Pedoman Penyelesaian Masalah Hak Ulayat Masyarakat Hukum Adat.

Undang - Undang Republik Indonesia Nomor 5 Tahun 1960 tentang Peraturan Dasar Pokok - Pokok Agraria. 